TELEIOS: Jurnal Teologi dan Pendidikan Agama Kristen

Sekolah Tinggi Teologi Transformasi Indonesia

ISSN 2798-0642 (Online), 2798-1797 (Print)

Volume 1, Nomor 2, Desember 2021 (155-167)

DOI: 10.53674/teleios.v1i2.39

stttransformasi-indonesia.ac.id/e-journal/index.php/teleios/index

\title{
Dampak Keterampilan Guru Pendidik Agama Kristen Terhadap Motivasi Belajar Siswa
}

\author{
${ }^{1}$ Anita Grays Pantow, ${ }^{2}$ Ribka Ester Legi \\ 1,2,3 Sekolah Tinggi Teologi Transformasi Indonesia \\ '1 graysanita17@gmail.com, ${ }^{2}$ ribkaesther03@gmail.com
}

\begin{abstract}
Abstrak:
Kajian ini menguraikan secara spesifik mengenai dampak ketrampilan guru Pendidik Agama Kristen dalam meningkatkan motivasi belajar siswa. Topik ini diangkat kara data faktual yang diterima peneliti, masih banyak ditemui para siswa dalam sebuah institusi motivasi belajar belum sepenuhnya antusias. Hal ini bisa disebabkan kurang terampilnya pendidik dalam mengajar. Tulisan ini menggunakan metode kualitatif dengan pendekatan deskriptif. Prosedur penelitian ini dilakukan dengan cara mengumpulkan data-data tentang dampak keterampilan guru PAK. Hasil uraian topik ini mengemukakan bahwa sebagai pengajar, guru dituntut untuk memiliki kecakapan dalam mengembangkan keterampilan mengajar. Adapun wujud dari ketrampilan pengajar itu mampu memahami isi Alkitab dengan baik dan benar, pengajar PAK mampu menjembatani persoalan dengan Alkitab. Kemudian pengajar PAK dapat membimbing dan mendampingi peserta didik, serta pengajar PAK hendaknya memahami dan menetapkan tujuan pengajaran yang diajarkan kepada nara-didik . Dengan ketrampilannya sebagai pendidik, motivasi nara-didik akan tercipta karena guru menjadi role model mereka untuk meningkatkan intensitas belajar.
\end{abstract}

Kata Kunci: Keterampilan Mengajar, Guru, Murid

\begin{abstract}
:
This study outlines the specifics of the impact of Christian Educator teacher skills in improving students' learning motivation. This topic is raised kara factual data received by researchers, there are still many students in a learning motivation institution not yet fully enthusiastic. This can be due to the lack of skilled educators in teaching. This paper uses qualitative methods with a descriptive approach. This research procedure is carried out by collecting data on the impact of PAK teachers' skills. The results of this topic description suggest that as teachers, teachers are required to have proficiency in developing teaching skills. As for the form of the teaching skills, it is able to understand the contents of the Bible properly and correctly, PAK teachers are able to bridge the problem with the Bible. Then PAK teachers can guide and accompany learners, and PAK teachers should understand and set the teaching objectives taught to learners. With his skills as an educator, the motivation of learners will be created because teachers become their role models to increase the intensity of learning.
\end{abstract}

Keywords: Teaching Skills, Teachers, Students 


\section{Pendahuluan}

Guru merupakan salah satu faktor penentu keberhasilan setiap upaya pendidikan. Itulah sebabnya guru harus menciptakan inovasi dalam kurikulum serta selalu meningkatkan kemampuan sumber daya manusianya melalui belajar yang terus-menerus. ${ }^{1}$ Proses belajar mengajar merupakan inti dari proses pendidikan dan guru sebagai pemegang peran utama. Guru dituntut memiliki multi peran, sehingga mampu menciptakan kondisi belajar mengajar yang efektif. ${ }^{2}$ Dalam proses pembenahan dan peningkatan kualitas pendidikan, telah ditetapkan Sistem Pendidikan Nasional yang ditetapkan dalam Undang-Undang Nomor 20 Tahun 2003. Sementara upaya pemerintah untuk mengangkat standard nasional pendidikan, dari keterperosokan maka telah di tetapkan dalam Peraturan Pemerintah Nomor 19 Tahun 2005.

Profesi guru Pendidikan Agama Kristen saat ini menjadi pembicaraan dikalangan pendidikan maupun diluar pendidikan. Berdasarkan fakta, bahwa SMP Negeri 1 Manado ada beberapa siswa tidak hadir saat mata pelajaran Agama Kristen ${ }^{3}$. Alasannya karena bosan dengan cara mengajar guru yang monoton. Seharusnya jika siswa-siswa merasa bosan, maka sebaiknya guru Pendidikan Agama Kristen harus mencari cara yang tepat dan menarik agar siswa tidak bosan lagi dan tidak absen. Fakta lainnya menunjukkan bahwa siswa-siswa SMP Negeri 1 Manado, menghormati guru Pendidikan Agama Kristen, hanya karena untuk memperoleh nilai yang baik, jika tujuan siswa-siswa sudah tercapai maka sikap menghormati sudah tidak tampak dalam pribadi siswa. ${ }^{4}$

Seharusnya nilai-nilai Alkitabiah ditanamkan kepada setiap siswa agar tidak saja belajar Pendidikan Agama Kristen untuk memperoleh nilai, tapi untuk bisa tertanam nilai-nilai Kekristenan yang berdasarkan Alkitab pada pribadi siswa sehingga memiliki karakter Kristus. Sama seperti Rasul Paulus ajarkan kepada jemaat di Efesus: "Hai anak-anak, taatilah orang tuamu di dalam Tuhan, karena haruslah demikian." (Ef 6:1). Orang tua disini tidak sebatas bapak dan ibu dari siswa, tetapi setiap orang yang lebih tua, termasuk guru yang bertanggung jawab atas perkembangan moral. Hasil wawancara dengan beberapa siswa menunjukkan bahwa ada beberapa guru yang hanya asal-asalan dalam memberikan materi dan tidak disiplin waktu, kebanyakan siswa tidak paham dengan pengajaran guru dan juga ada beberapa guru yang melanggar kode etik berupa berlaku kasar terhadap para siswa seperti memukul dan mengucapkan kata-kata yang menyakiti siswa. ${ }^{5}$ Danny Jonatan Turanga mengemukakan seorang guru Pendidikan Agama Kristen, tidak hanya mengajarkan dan mentransfer ilmu pengetahuan, tetapi yang terutama adalah mentransfer nilai-nilai dalam rangka pembentukan sikap termasuk sikap empati kepada orang lain. Oleh sebab itu sosok seorang guru adalah

\footnotetext{
${ }^{1}$ B Samuel Sidjabat, "Menjadi Guru Profesional Sebuah Perspektif Kristiani," Jabar: IKAPIR (2000).

${ }^{2}$ Dewi Safitri, S Sos, and others, Menjadi Guru Profesional (PT. Indragiri Dot Com, 2019).

${ }^{3}$ Wawancara dengan Bpk. James, orang tua siswa kelas VII SMP Negeri 1 Manado di ruang guru pada tanggal 14 Agustusi 2021 pkl 10.00 WITA.

${ }^{4}$ Wawancara dengan Niko, siswa kelas VII SMP Negeri 1 Manado di halaman Sekolah tanggal 14 Agustusi 2021 pkl 10.30 WITA

${ }^{5}$ Wawancara dengan Joseph, siswa kelas VIII SMP Negeri 1 Manado, pada tanggal 14 Agustus 2021 pkl 11.00 WITA.
} 
pribadi yang bisa dijadikan panutan, teladan dan contoh bagi anak didik. Itulah sebabnya seorang guru harus memiliki kualitas kompetensi profesionalisme guru dan kompetensi pedagogic, sebagai pembawa informasi dalam komunikasi intra personal.

Seorang guru Pendidikan Agama Kristen tidak berlaku kasar dan keras kepada anak didik, karena tidak sesuai dengan kebenaran firman Tuhan. Rasul Paulus mengajarkan kepada jemaat di Efesus bahwa: "Dan kamu, bapa-bapa, jangan membangkitkan amarah di dalam hati anak-anakmu, tetapi didiklah mereka di dalam ajaran dan nasihat Tuhan." (Ef 6:4). Anak-anak disini tidak saja sebatas anak kandung, tetapi anak-anak didik juga termasuk didalamnya. Itulah sebabnya seorang guru Pendidikan Agama Kristen haruslah mempunyai kompetensi, dan memenuhi syarat untuk kriteria-kriteria tertentu serta sudah bertumbuh dalam rohani, sehingga mengeluarkan buah Roh menurut Galatia 5:22. Dengan demikian maka seorang guru Pendidikan Agama Kristen memiliki karakter Kristus. Hal demikian akan membuat anak didik menjadi senang dan termotivasi untuk terus belajar serta dapat mengambil contoh dari guru. ${ }^{6}$

Guru merupakan profesi yang memerlukan keahlian khusus. Pekerjaan ini tidak dapat dilakukan oleh orang-orang diluar pendidikan. Hal ini disebabkan karena tugas guru berkaitan dengan pembinaan sifat mental manusia. Banyak guru yang belum berusaha mengembangkan profesinya. Salah satu kelemahan yang terdapat pada diri guru diantaranya rendahnya tingkat kompetensi dan ketrampilan. ${ }^{7}$ Penguasaan guru terhadap materi dan metode pengajaran masih dibawah standard. ${ }^{8}$ Agar tercapainya proses belajar mengajar yang efektif, guru harus meningkatkan kesempatan belajar bagi siswa dan meningkatkan kualitas mengajar, dengan cara melibatkan siswa secara aktif dalam belajar. Makin banyak siswa terlibat aktif dalam belajar, makin tinggi kemungkinan prestasi belajar yang dicapai. ${ }^{9}$ Untuk meningkatkan kualitas mengajar, maka perlu bagi guru untuk merencanakan program pengajaran yang interaktif.

Keberhasilan seorang guru akan menimbulkan kepuasan, rasa percaya diri serta semangat mengajar yang tinggi bagi diri guru tersebut. Ini menunjukkan sebagian sikap guru profesional, yang terampil. Hal ini dibutuhkan. Pendidikan dilakukan sepanjang kehidupan manusia, dan dimulai dari dalam lingkungan keluarga, sekolah dan masyarakat. Itulah sebabnya pendidikan merupakan tanggung jawab bersama antara keluarga, masyarakat dan pemerintah. Sudah saatnya kompetensi profesi guru ditingkatkan. Guru perlu tampil disetiap kesempatan sebagai pendidik, pengajar, pelatih, inovator maupun dinamisator pembangunan masyarakat. ${ }^{10}$

${ }^{6}$ danny Jonatan Turangan, "Kompetensi Pedagogik Guru Pendidikan Agama Kristen Berpengaruh Pada Motivasi Belajar Siswa Di Sd Gmim Ii Madidir Ure Kota Bitung," Apolonius: Jurnal Teologi dan Pendidikan Kristen 2, no. 1 (2021): 1-20.

7 Juhji Juhji, "Peran Urgen Guru Dalam Pendidikan,” Studia Didaktika 10, no. 01 (2016): 51-62.

${ }^{8}$ Wawancara dengan Kepala Sekolah SMP Negeri 1 Manado di ruang Kepala Sekolah pada tanggal 14 Agustus 2021 pkl 11.30 WITA.

${ }^{9}$ Syaparuddin Syaparuddin, Meldianus Meldianus, and Elihami Elihami, "Strategi Pembelajaran Aktif Dalam Meningkatkan Motivasi Belajar Pkn Peserta Didik," Mahaguru: Jurnal Pendidikan Guru Sekolah Dasar 1, no. 1 (2020): 30-41.

${ }^{10}$ Mohammad Roqib and Nurfuadi Nurfuadi, "Kepribadian Guru” (CV. Cinta Buku, 2020). 
Guru Pendidikan Agama Kristen di sekolah memegang peran penting ketika anak didik ada disekolah. Guru sebagai pengganti orang tua di sekolah dituntut perannya seperti orang tua dan juga sebagai pendidik, bukan hanya mentransfer ilmu pengetahuan tetapi juga mentransfer nilai-nilai untuk pembentukan sikap empati kepada orang lain. ${ }^{11}$ Itulah sebabnya guru sebagai panutan anak, teladan dan sebagai figur yang layak dicontohi. Itulah sebabnya seorang guru Pendidikan Agama Kristen haruslah memiliki kualitas kompetensi profesionalisme guru yang baik sebagai pembawa informasi dalam komunikasi antar personal. Untuk pembahasan lebih dalam lagi, tentang Ketrampilan Guru Pendidikan Agama Kristen Meningkatkan Motivasi Belajar Siswa, maka pertanyaan penelitian utama pada topik apa itu keterampilan guru Pendidikan Agama Kristen? Kemudian bagaimana ketrampilan guru Pendidikan Agama Kristen terhadap motivasi belajar siswa? Pertanyaan-pertanyaan tersebut diatas, akan diuraikan pada kajian topik ini. Harapan penulis, penelitian ini memberikan kontribusi yang berarti, sehingga semakin diperkaya dalam literatur berbasis keagaman.

\section{Metode Penelitian}

Adapun metode penelitian ini menggunakan metode kualitatif dengan pendekatan deskriptif Metode kualitatif adalah metode penelitian yang pemecahan masalahnya menggunakan data empiris. ${ }^{12}$ Dengan demikian penelitian ini tertuju pada pemecahan masalah yang ada. Pelaksanaan metode deskriptif tidak terbatas hanya sampai pengumpulan data saja, tetapi meliputi analisa terhadap data yang menggambarkan apa adanya tentang suatu variable, gejala dan keadaan. ${ }^{13}$ Proserdur penelitian ini dilakukan dengan cara mengumpulkan data-data tentang dampak keterampilan guru PAK. Data-data diambil dari sumber-sumber kepustakaan pendidikan agama Kristen dari buku, jurnal, dan berita online termasuk data juga dikumpulkan dengan cara wawancara. Data-data tersebut kemudian direduksi dan dikelompokkan berdasarkan pokok masalah. Kemudian data yang sudah direduksi, dianalisa dan disimpulkan.

\section{Hasil dan Pembahasan}

\section{Keterampilan Mengajar Pendidik Agama Kristen}

Sebagai pengajar, guru dituntut untuk memiliki kecakapan dan mengembangkan keterampilan mengajar. Ada beberapa keterampilan yang perlu dikuasai dan dikembangkan oleh seorang guru pendidikan agama Kristen, dalam mengembangkan profesinya. ${ }^{14}$ Adapun keterampilan yang perlu dikuasai dan dikembangkan oleh seorang pengajar PAK pertama mampu memahami isi Alkitab dengan baik dan benar. Alkitab adalah pusat pengajaran

\footnotetext{
11 Turangan, "Kompetensi Pedagogik Guru Pendidikan Agama Kristen Berpengaruh Pada Motivasi Belajar Siswa Di Sd Gmim Ii Madidir Ure Kota Bitung."

${ }^{12}$ M Zainuddin Mansyuri, "Metode Penelitian: Pendekatan Praktis Dan Aflikatif Edisi Revisi," Bandung. Refika Aditama (2011).

${ }^{13}$ Surakhmad Winarno, "Pengantar Penelitian Ilmiah,” Bandung: Tarsito (1994).

${ }^{14}$ Sumiati Sumiati, Steaven Octavianus, and Reni Triposa, "Aplikasi Teori Kecerdasan Majemuk Pada Mata Pelajaran PAK Di Sekolah Inklusi," CHARISTHEO: Jurnal Teologi dan Pendidikan Agama Kristen 1, no. 1 (2021): 102-121.
} 
pendidikan agama Kristen. Karena itu Alkitab harus di tafsir dengan pertimbangan latar belakang teks dan konteks. Guru PAK harus memiliki kemampuan untuk memahami serta menafsir teks Alkitab secara baik dan benar supaya peserta didik dapat menerima pesan Alkitab dengan benar. ${ }^{15}$ Kedua pengajar PAK mampu menjembatani persoalan dengan Alkitab. Pelajaran pendidikan agama Kristen yang diperoleh peserta didik bisa bermanfaat, jika bersentuhan dengan kehidupan sehari-hari. Pelajaran ini hendaknya membantu peserta didik menghadapi berbagai persoalan hidup. Tugas guru pendidikan agama Kristen adalah menjembatani persoalan hidup sehari-hari dengan pelajaran firman Tuhan. ${ }^{16}$

Ketiga, pengajar PAK dapat membimbing dan mendampingi peserta didik. Pembelajaran pendidikan agama Kristen hendaknya memiliki makna bagi peserta didik. Karena itu pendampingan guru pendidikan agama Kristen sangat menentukan apakah peserta didik mengalami transformasi nilai-nilai kehidupan sebagai murid Yesus atau tidak. Sebaliknya guru pendidikan agama Kristen sebagai panutan dan model bagi peserta didik sangat diperlukan. ${ }^{17}$ Potret diri guru turut menentukan penerimaan terhadap nilai-nilai iman Kristiani. Jika potret guru buram, maka nilai-nilai yang diajarkan sukar untuk diterima oleh peserta didik. Tapi jika potret diri guru baik, maka nilai-nilai yang diajarkan akan lebih mudah diterima peserta didik. Keempat, pengajar PAK hendaknya memahami dan menetapkan tujuan pengajaran yang diajarkan kepada nara-didik. Guru PAK harus mampu memahami dan menetapkan pengajaran dengan baik. Karena hal itu sangat berpengaruh dalam pelaksanaan proses belajar mengajar. ${ }^{18}$ Tujuan pengajaran dapat memberikan manfaat bagi guru, diantaranya memberi arah ke mana peserta didik akan dibawa untuk mengalami perobahan. Menolong guru untuk merencanakan pendekatan yang tepat dalam mengajarkan bahan yang dirumuskan.

Akhirnya guru dipanggil untuk membagikan harta abadi yaitu keselamatan kepada peserta didik. Karena itu sebagai seorang pengajar, guru dituntut untuk memiliki keterampilan mengajar. Keterampilan ini sangat mendukung pencapaian tujuan pembelajaran di kelas. Keterampilan tidak dibawa sejak lahir, seperti bakat tetapi harus dilatih terus-menerus secara intensif sehingga sampai pada tingkat mahir untuk melakukan sesuatu. Itulah sebabnya seorang guru perlu belajar untuk meningkatkan keterampilannya supaya terus berkembang. Dengan kekuatan dan hikmat Tuhan, keterampilan dapat meningkat mencapai tingkat professional. Guru perlu belajar menjadi pribadinya sebagai instrument yang handal dan terampil di hadapan Tuhan, sebagaimana Yesus sebagai Guru.

\footnotetext{
15 Sumiati Sumiati and Reni Triposa, "Prinsip Guru Pendidikan Agama Kristen Memotivasi Belajar Peserta Didik Dalam Perspektif Alkitab," Harati: Jurnal Pendidikan Kristen 1, no. 1 (2021): 69-84.

${ }^{16}$ Noh Ibrahim Boiliu, "Misi Pendidikan Agama Kristen Dan Problem Moralitas Anak," Jurnal Pendidikan Agama Kristen (Regula Fidei) 1, no. 1 (2016): 115-140.

17 Yonatan Alex Arifianto, "Peran Guru Pendidikan Agama Kristen Dalam Pendidikan Etis-Teologis Mengatasi Dekadensi Moral Di Tengah Era Disrupsi," REGULA FIDEI: Jurnal Pendidikan Agama Kristen 6, no. 1 (2021): 45-59.

18 Arozatulo Telaumbanua, "Peranan Guru Pendidikan Agama Kristen Dalam Membentuk Karakter Siswa,” FIDEI: Jurnal Teologi Sistematika dan Praktika (2018).
} 


\section{Kompetensi Guru PAK yang Profesional}

Seorang guru pendidikan agama Kristen, harus memiliki kompetensi-kompetensi untuk berperan sebagai guru yang professional. Adapun kompetensi itu diantaraya pertama kompetensi pedagogik. Kompetensi ini memahami peserta didik secara mendalam. Kompetensi ini mempunyai indikator memahami peserta didik dengan memanfaatkan prinsip-prinsip keptribadian; serta mengidentifikasi bekal ajar awal peserta didik. Itu berarti seorang guru harus memahami kepribadian serta kemampuan setiap peserta didik, agar bisa menerapkan metode mengajar yang sesuai dengan kemampuan peserta didik. ${ }^{19}$ Kompetensi pedagogik juga merancang pembelajaran dengan tujuan memahami landasan pendidikan, dengan menerapkan teori belajar serta menentukan strategi pembelajaran berdasarkan karateristik peserta didik. ${ }^{20}$ Kompetensi pedagogik juga berkaitan mengembangkan peserta didik untuk pengembangan berbagai potensi akademik dan non akademik. Peserta didik yang berpotensi dibimbing agar berkembang. Kedua, kompetensi kepribadian. Kompetensi kepribadian terdiri dari kepribadian yang mantap, dewasa, bijaksana, berwibawa dan berakhlak mulia. Kompetensi kepribadain bertindak sesuai dengan norma hukum; norma sosial dan memiliki konsistensi dalam bertindak sesuai dengan norma. Kompetensi kepribadian yang dewasa menampilkan kemandirian dalam bertindak sebagai pendidik dan memiliki etos kerja sebagai guru. ${ }^{21}$ Sedang kompetensi kepribadian yang bijaksana menampilkan tindakan yang didasarkan pada apa yang bermanfaat bagi peserta didik, sekolah dan masyarakat. Kompetensi kepribadian yang berwibawa perilaku yang berpangaruh positif pada peserta didik serta disegani. ${ }^{22}$ Sedang kompetensi kepribadian akhlak mulia bertindak sesuai dengan norma agama dan memilki perilaku yang bisa diteladani oleh peserta didik. Kepribadian seorang guru akan sangat mewarnai kinerjanya dalam mengelola kelas dan berinteraksi dengan siswa. ${ }^{23}$

Kompetensi ketiga yang harus dimiliki pengajara PAK adalah memiliki Kompetensi Sosial. Kompetensi sosial meliputi mampu berkomunikasi dan bergaul secara efektif dengan peserta didik. Mampu berkomunikasi dan bergaul secara efektif dengan kesesama pendidik. Ia juga mampu berkomunikasi dan bergaul secara efektif dengan orang tua/wali peserta didik dan masyarakat disekitarnya. Guru yang secara sosial bisa berinteraksi dengan siswanya akan menjadi pengelola kelas yang baik. ${ }^{24}$ Kompetensi keempat adalah Kompetensi Profesional. Kompetensi professional menguasai keilmuan yang terkain dengan bidang studi. Indikatornya memahami materi ajar yang terdapat dalam kurikulum sekolah; memahami struktur, konsep

${ }^{19}$ Ester Putri Setiyowati and Yonatan Alex Arifianto, "Hubungan Kompetensi Pedagogik Guru Dan Prestasi Belajar Siswa Pada Mata Pelajaran Pendidikan," SIKIP Jurnal Pendidikan Agama Kristen 1, no. 2 (2020): 78-95.

${ }^{20}$ Ibid.

${ }^{21}$ Rinto Hasiholan Hutapea, "Meneropong Kompetensi Kepribadian Guru Pendidikan Agama Kristen Sebagai Model Perilaku Peserta Didik," Veritas Lux Mea (Jurnal Teologi dan Pendidikan Kristen) 1, no. 2 (2019): 66-75.

22 Ibid.

23 Talizaro Tafona'o, “Kepribadian Guru Kristen Dalam Perspektif 1 Timotius 4: 11-16," Evangelikal: Jurnal Teologi Injili dan Pembinaan Warga Jemaat 3 (2019): 62-81.

24 Ibid. 
dan metode keilmuan yang menaungi. Memahami hubungan konsep antar mata pelajaran terkait dan menerapkan konsep-konsep keilmuan dalam kehidupan sehari-hari. ${ }^{25}$ Kompetensi professional ini juga diukur dari Menguasai struktur dan metode keilmuan, indikatornya menguasai langkah-langkah penelitian dan kajian kritis untuk memperdalam pengetahuan materi bidang studi. Kompetensi kelima yang perlu dimiliki oleh pendidik PAK adalah kompetensi spiritual. Kompetensi spiritual harus benar-benar dijaga dari hal-hal yang dapat merusak nama baik guru pendidikan agama Kristen, karena kehidupan rohani dari seorang guru pendidikan agama Kristen harus menjadi panutan dan teladan yang mencerminkan kehidupan Tuhan Yesus Kristus. ${ }^{26}$

\section{Faktor-faktor yang Berpengaruh pada Perkembangan peserta didik}

Beragam factor yang memengaruhi perkembangan peserta didik dalam proses pembelajaran. Adapun factor itu diantaranya kondisi fisik. Fisik merupakan fatokr biologis individu yang merujuk pada faktor genetik yang diturunkan oleh kedua orang tua. Pada masa pembentukan sel-sel tubuh, banyak factor dapat mempengaruhi kondisi janin disamping keunikan yang telah ada pada kedua orang tuanya. ${ }^{27}$ Kemudian ada faktor kondisi psikis. Kondisi fisik dan psikis setiap orang sangat berkaitan. Perkembangan individu menyangkuat fisik, intelektual meliputi kognitif dan bahasa, emosi, sosial dan moral. Kondisi fisik yang tidak sempurna berkaitan dengan persepsi individu terhadap kemampuan dirinya. Begitupun ketidakmampuan intelektual dapat disebabkan karena kerusakan system syaraf, kerusakan otak atau mengalami gangguan mental. ${ }^{28}$ Factor dari lingkungan fisik juga berperan memengaruhi perkembangan proses pembelajaran bagi nara-didik. Lingkungan ini mencakup kondisi keamanan, cuaca, keadaan geografis, kebersihan lingkungan serta keadaan rumah yang meliuti ventilasi, cahaya dan kepadatan hunian. Semua kondisi ini sangat mempengaruhi bagaimana individu dapat menjalankan proses kehidupan. Ada juga factor lingkungan non fisik. Lingkungan non fisik meliputi berbagai macam komponen yaitu keluarga, pendidikan dan masyarakat. Beberapa faktor yang berkaitan dengan lingkungan non fisik seperti motivasi dalam mempelajari sesuatu, pola asuh, serta kasih saying dari orang tua. ${ }^{29} \mathrm{~s}$

\section{Fungsi Motivasi Belajar}

Motivasi belajar adalah suatu dorongan kehendak yang menyebabkan seseorang melakukan suatu perbuatan untuk mencapai tujuan tertentu. Motivasi adalah suatu dorongan

\footnotetext{
25 Junaydi Alexander Sagala, "Kualifikasi Kepribadian Guru Agama Kristen," in Seminar Nasional Pendidikan Agama Kristen Dan Call for Papers, 2017.

${ }^{26}$ Delipiter Lase and Etty Destinawati Hulu, "Dimensi Spritualitas Dalam Kompetensi Kepribadian Guru Pendidikan Agama Kristen," SUNDERMANN: Jurnal Ilmiah Teologi, Pendidikan, Sains, Humaniora dan Kebudayaan 13, no. 1 (2020): 13-25.

${ }^{27}$ Naeklan Simbolon, "Faktor-Faktor Yang Mempengaruhi Minat Belajar Peserta Didik," Elementary School Journal Pgsd Fip Unimed 1, no. 2 (2014).

28 Ibid.

${ }^{29}$ Ibid.
} 
internal dan eksternal dalam diri seseorang yang diindikasikan dengan adanya hasrat dan minat; dorongan dan kebutuhan; harapan dan cita-cita; pengharapan dan penghormatan. ${ }^{30}$ Motivasi dapat membuat seseorang bertindak atau motivasi merupakan dampak dari interaksi seseorang dengan situasi yang dihadapinya. Orang yang mengalami persoalan terdorong untuk bertindak agar keluar dari masalah. Motivasi merupakan kondisi psikologis yang mendorong seseorang untuk melakukan sesuatu. Hal inilah yang perlu dimiliki oleh seorang guru untuk kelancaran dan kesuksesan proses pembelajaran yang dilakukannya. Jika menghendaki anak didik tetap focus pada pelajaran, tentu guru harus selalu memberikan motivasi.

Adapun fungsi dari motivasi adalah Mendorong manusia untuk berbuat sesuatu. Sebagai penggerak atau motor yang melepaskan energy, motivasi merupakan penggerak dari setiap kegiatan yang dikerjakan. Seorang guru adalah motor atau penggerak untuk mendorong peserta didik bertindak untuk belajar. ${ }^{31}$ Fungsi berikutnya dari motivasi adalah menentukan arah perbuatan. Motivasi memberikan dua arah dan kegiatan yang harus dikerjakan sesuai dengan rumusan tujuannya. Untuk menentukan arah mana yang akan diambil, maka melalui motivasi seseorang akan dapat menyeleksi tindakan apa yang hendak dilakukan lebih dahulu atau sesuatu yang menjadi prioritas dalam bertindak. Fungsi motivasi berikutnya menyeleksi perbuatan. Motivasi juga membuat seseorang akan menyeleksi tindakan-tindakan apa yang lebih diprioritaskan, itulah yang terlebih dahulu di kerjakan. Seseorang yang termotivasi, akan memilih dan menyeleksi tindakan yang menjadi prioritas. ${ }^{32}$

\section{Strategi Menumbuhkan Motivasi}

Motivasi adalah perubahan energy dalam diri seseorang yang ditandai dengan munculnya "feeling" yang didahului dengan tanggapan terhadap adanya tujuan. Tiga elemen penting untuk menumbuhkan motivasi. Pertama, motivasi dimulai dengan suatu perubahan tenaga dalam diri seseorang. Perkembangan motivasi akan membawa beberapa perubahan energy di dalam system "neurophysiological" yang ada pada organisme tubuh manusia. ${ }^{33}$ Karena adanya perubahan energy, maka akan menyangkut kegiatan fisik. Kedua, motivasi ditandai oleh dorongan afektif. Motivasi ditandai dengan munculnya rasa/feeling afeksi seseorang. Motivasi relevan dengan persoalan-persoalan kejiwaan. Afeksi dan emosi yang dapat menentukan tingkah lau manusia. Ketiga, Motivasi ditandai oleh reksi-reaksi untuk mencapai tujuan. Motivasi akan dirangsang karena adanya tujuan. Jadi motivasi dalam hal ini sebenarnya merupakan respons dari suatu aksi, yaitu tujuan. Motivasi memang muncul dari dalam diri

\footnotetext{
${ }^{30}$ KBBI, “Arti Kata Belajar - Kamus Besar Bahasa Indonesia (KBBI) Daring,” Kementerian Pendidikan Dan Kebudayaan Republik Indonesia, 2018.

${ }^{31}$ Ahmad Idzhar, "Peranan Guru Dalam Meningkatkan Motivasi Belajar Siswa," Jurnal office 2, no. 2 (2016): 221-228.

32 ARIANTI ARIANTI, "Peranan Guru Dalam Meningkatkan Motivasi Belajar Siswa," Didaktika: Jurnal Kependidikan 12, no. 2 (2019): 117-134.

33 Ibid.
} 
manusia, tetapi kemunculannya karena terangsang atau terdorong oleh adanya unsur lain, yaitu tujuan yang hendak dicapai. ${ }^{34}$

\section{Peran Guru Agama Kristen Dalam Menumbuhkan Motivasi Belajar}

Perkembangan terhadap dunia pendidikan membawa konsekuensi kepada guru untuk terus meningkatkan peranan dan keompetensinya, karena proses belajar mengajar sangat di tentukan oleh peranan dan kompetensi guru. Guru yang kompeten akan lebih mampu menciptakan lingkungan belajar yang efektif dan akan mampu mengelola kelasnya seingga hasil belajar siswa optimal. Peranan dan kompetensi guru dalam proses belajar-mengajar meliputi banyak hal antara lain pendidik PAK berperan sebagai sebagai demonstran. ${ }^{35}$ Melalui perannya sebagai demonstrator, guru hendaknya menguasai materi pelajaran yang akan diajarkan serta selalu mengembangkannya. Dengan demikian seorang guru PAK haruslah belajar terus-menerus, karena dengan cara inilah maka seorang guru akan dapat memperkaya dirinya dengan berbagai ilmu pengetahuan sebagai bekal dalam melaksanakan tugasnya sebagai pengajar dan demonstrator. ${ }^{36}$ Seorang guru hendaknya mampu dan terampil dalam merumuskan tujuan pembelajaran khusus, memahami kurikulum, dan dia sendiri sebagai sumber belajar yang terampil memberikan informasi di kelas. Iapun harus membantu perkembangan anak didik untuk dapat menerima, memahami serta menguasai ilmu pengetahuan. Guru pendidikan agama Kristen juga harus terampil dalam memanfaatkan berbagai sumber belajar untuk memperjelas informasi yang akan disampaikan kepada peserta didik.

Kemudian peran pengajar PAK adalah ia sebagai pengelola kelas. Peran sebagai pengelola kelas, guru haruslah mampu mengelola kelas sebagai lingkungan belajar serta merupakan aspek dari lingkungan sekolah yang perlu diorganisir. Lingkungan ini diatur dan diawasi agar kegiatan belajar terarah kepada tujuan pendidikan. ${ }^{37}$ Pengawasan terhadap belajar lingkungan turut menentukan sejauh mana lingkungan tersebut menjadi lingkungan belajar yang baik. Lingkungan yang baik bersifat menantang dan merangsang siswa untuk belajar, memberikan rasa aman dan kepuasan dalam mencapai tujuan. Kualitas dan kuantitas belajar siswa di dalam kelas bergantung pada banyak faktor, antara lain guru, hubungan pribadi antara siswa di dalam kelas.

Tujuan pengelolaan kelas adalah menyediakan dan menggunakan fasilitas kelas untuk bermacam-macam kegiatan belajar mengajar agar mencapai hasil yang lebih baik. Secara khusus tujuan pengelolaan kelas agar siswa dapat mengembangkan kemampuan dengan menggunakan alat-alat belajar. Salah satu manajemen kelas yang baik ialah menyediakan

\footnotetext{
${ }^{34}$ Idzhar, "Peranan Guru Dalam Meningkatkan Motivasi Belajar Siswa."

${ }^{35}$ Rifai Rifai, "Penerapan Metode Demonstrasi Untuk Meningkatkan Hasil Belajar Pendidikan Agama Kristen Materi Pembelajaran Sakramen Perjamuan Kudus VIII SMP Negeri 17 Surakarta, Tahun 2015/2016," DUNAMIS: Jurnal Teologi dan Pendidikan Kristiani 1, no. 2 (2017): 171-191.

36 Ibid.

${ }^{37}$ Hana Suparti and Ezra Tari, "Etos Kerja Profesional Guru Pendidikan Agama Kristen," REGULA FIDEI: Jurnal Pendidikan Agama Kristen 4, no. 2 (2019): 137-146.
} 
kesempatan bagi siswa untuk sedikit demi sedikit mengurangi ketergantungannya pada guru dan mampu membimbing kegiatannya sendiri. ${ }^{38}$ Siswa harus belajar melakukan kontrol sendiri, dan aktivitas sendiri secara bertahap. Sebagai pengelola lingkungan belajar, guru harus mampu gunakan teori belajar dengan baik. Pengelolaan kelas diusahakan menciptakan suasana yang menyenangkan, agar peserta didik tidak merasa tertekan karena sikap guru yang kasar, marah, emosi dan lain sebagainya.

Peran lain yang dapat dilakukan oleh pendidik PAK ia sebagai mediator dan fasilitator. Sebagai mediator guru harus memiliki pengetahuan yang cukup tentang media pendidikan karena merupakan alat komunikasi agar proses belajar-mengajar lebih efektif. Guru juga harus memiliki ketrampilan memilih dan menggunakan serta mengusahakan media pedidikan dengan baik. ${ }^{39}$ Oleh sebab itu diperlukan latihan-latihan praktek secara kontinu dan sistematis. Sebagai mediator guru menjadi perantara dalam hubungan antar manusia. Untuk itu guru harus terampil mempergunakan pengetahuan tentang bagaimana berinteraksi dan berkomunikasi. Tujuannya agar dapat menciptakan secara maksimal kualitas lingkungan yang interaktif. Sebagai fasilitator guru harus mampu mengusahakan sumber belajar yang berguna serta dapat menunjang pencapaian tujuan dan proses belajar-mengajar, baik nara sumber, buku teks, majalah mapun surat kabar. ${ }^{40}$

Peran lain dari penddik PAK ia berperan sebagai evaluator. Dalam dunia pendidikan dalam satu perode tertentu perlu untuk diadakan evaluasi, artinhya pada waktu-waktu tertentu selama periode pendidikan, diadakan penilaian terhadap hasil yang telah dicapai, baik oleh siswa maupun oleh pendidik. Demikian juga dalam satu kali proses belajar-mengajar guru haruslah menjadi seorang evaluator yang baik. ${ }^{41}$ Kegiatan ini dimaksudkan untuk mengetahui apakah tujuan yang telah dirumuskan itu tercapai atau belum, dan materi yang diajarkan sudah cukup tepat. Semua pertanyaan tersebut akan dapat dijawab melalui kegiatan evaluasi atau penilaian.

Dengan penilaian guru dapat mengetahui keberhasilan pencapaian tujuan, penguasaan siswa terhadap pelajaran, serta ketepatan atau efektifitas metode mengajar. Tujuan mengklasifikasi apakah seorang siswa termasuk kelompok siswa yang pandai, sedang. kurang atau cukup baik dikelasnya jika dibandingkan dengan teman-temannya. Dengan menelaah pencapaian tujuan pengajaran, guru dapat mengetahui apakah proses belajar-mengajar yang dilakukan cukup efektif memberikan hasil yang baik dan memuaskan, atau sebaliknya. ${ }^{42}$ Jadi

38 Dwiati Yulianingsih, Lumban Gaol, and Stefanus Marbun, "Keterampilan Guru PAK Untuk Meningkatkan Minat Belajar Murid Dalam Proses Pembelajaran Di Kelas," FIDEI: Jurnal Teologi Sistematika dan Praktika 2, no. 1 (2019): 100-119.

${ }^{39}$ Dorlan Naibaho, "Peranan Guru Sebagai Fasilitator Dalam Perkembangan Peserta Didik," Jurnal Christian Humaniora 2, no. 1 (2018): 77-86.

40 Ibid.

${ }^{41}$ Sri Sukmi Putriaty, "Lokakarya Yang Ditindaklanjuti Dengan Supervisi Akademik Diupayakan Untuk Meningkatkan Kemampuan Guru Bertindak Sebagai Evaluator, Motivator Dan Fasilitator Dalam Proses Pembelajaran Di Smpn 3 Sijuk Pada Semester 2 Tahun Pelajaran 2018/2019,” Daiwi Widya 6, no. 3 (2019).

42 Ibid. 
guru haruslah terampil untuk melaksanakan penilaian, karena dengan penilaian guru dapat mengetahui prestasi yang dicapai oleh siswa setelah ia melaksanakan proses belajar. Dalam fungsinya sebagai penilai hasil belajar siswa, guru haruslah terus-menerus mengikuti hasil belajar yang telah dicapai oleh siswa dari waktu ke waktu. Informasi yang diperoleh melalui evaluasi ini merupakan umpan balik terhadap proses belajar-mengajar. Umpan balik ini akan dijadikan titik tolak untuk memperbaiki dan meningkatkan proses belajar-mengajar selanjutnya.

\section{Kesimpulan}

Dari uraian topik di atas, guru PAK sudah sepatutnya memiliki keterampilan yang tinggi dalam suatu bidang serta mahir dalam menggunakan peralatan tertentu yang diperlukan dalam pelaksanaan tugas yang bersangkutan dalam bidangnya. Guru PAK juga memiliki ilmu dan pengalaman serta kecerdasan dalam menganalisis suatu masalah dan peka di dalam membaca situasi, cepat dan tepat serta cermat dalam mengambil keputusan yang terbaik. Memiliki sikap berorientasi ke depan sehingga punya kemampuan mengantisipasi perkembangan lingkungan dan memiliki sikap mandiri berdasarkan keyakinan akan kemampuan pribadi serta terbuka dan menghargai pendapat nara-didiknya. Spoint penting utamanya guru PAK memiliki spiitualitas yang mencerminkan nilai-nilai kebenaran Alkitab yang dapat menjadi teladan bagi siswa yang diajarnya. Dengan guru PAK terampil dalam kapabilitas dan spiritualitasnya diteladani, maka motivasi nara-didik dalam belajar akan meningkat. Dengan demikian, maka guru akan memiliki kehidupan yang mengandung nillai-nilai Alkitabiah, yang sangat berpengaruh bagi peserta didik.

\section{Referensi}

ARIANTI, ARIANTI. "Peranan Guru Dalam Meningkatkan Motivasi Belajar Siswa." Didaktika: Jurnal Kependidikan 12, no. 2 (2019): 117-134.

Arifianto, Yonatan Alex. "Peran Guru Pendidikan Agama Kristen Dalam Pendidikan EtisTeologis Mengatasi Dekadensi Moral Di Tengah Era Disrupsi." REGULA FIDEI: Jurnal Pendidikan Agama Kristen 6, no. 1 (2021): 45-59.

Boiliu, Noh Ibrahim. "Misi Pendidikan Agama Kristen Dan Problem Moralitas Anak." Jurnal Pendidikan Agama Kristen (Regula Fidei) 1, no. 1 (2016): 115-140.

Hutapea, Rinto Hasiholan. "Meneropong Kompetensi Kepribadian Guru Pendidikan Agama Kristen Sebagai Model Perilaku Peserta Didik." Veritas Lux Mea (Jurnal Teologi dan Pendidikan Kristen) 1, no. 2 (2019): 66-75.

Idzhar, Ahmad. "Peranan Guru Dalam Meningkatkan Motivasi Belajar Siswa." Jurnal office 2, no. 2 (2016): 221-228.

Juhji, Juhji. "Peran Urgen Guru Dalam Pendidikan.” Studia Didaktika 10, no. 01 (2016): 5162.

KBBI. “Arti Kata Belajar - Kamus Besar Bahasa Indonesia (KBBI) Daring.” Kementerian 
Pendidikan Dan Kebudayaan Republik Indonesia, 2018.

Lase, Delipiter, and Etty Destinawati Hulu. "Dimensi Spritualitas Dalam Kompetensi Kepribadian Guru Pendidikan Agama Kristen." SUNDERMANN: Jurnal Ilmiah Teologi, Pendidikan, Sains, Humaniora dan Kebudayaan 13, no. 1 (2020): 13-25.

Mansyuri, M Zainuddin. "Metode Penelitian: Pendekatan Praktis Dan Aflikatif Edisi Revisi." Bandung. Refika Aditama (2011).

Naibaho, Dorlan. "Peranan Guru Sebagai Fasilitator Dalam Perkembangan Peserta Didik." Jurnal Christian Humaniora 2, no. 1 (2018): 77-86.

Putriaty, Sri Sukmi. "Lokakarya Yang Ditindaklanjuti Dengan Supervisi Akademik Diupayakan Untuk Meningkatkan Kemampuan Guru Bertindak Sebagai Evaluator, Motivator Dan Fasilitator Dalam Proses Pembelajaran Di Smpn 3 Sijuk Pada Semester 2 Tahun Pelajaran 2018/2019." Daiwi Widya 6, no. 3 (2019).

Rifai, Rifai. "Penerapan Metode Demonstrasi Untuk Meningkatkan Hasil Belajar Pendidikan Agama Kristen Materi Pembelajaran Sakramen Perjamuan Kudus VIII SMP Negeri 17 Surakarta, Tahun 2015/2016." DUNAMIS: Jurnal Teologi dan Pendidikan Kristiani 1, no. 2 (2017): 171-191.

Roqib, Mohammad, and Nurfuadi Nurfuadi. "Kepribadian Guru.” CV. Cinta Buku, 2020.

Safitri, Dewi, S Sos, and others. Menjadi Guru Profesional. PT. Indragiri Dot Com, 2019.

Sagala, Junaydi Alexander. "Kualifikasi Kepribadian Guru Agama Kristen." In Seminar Nasional Pendidikan Agama Kristen Dan Call for Papers, 2017.

Setiyowati, Ester Putri, and Yonatan Alex Arifianto. "Hubungan Kompetensi Pedagogik Guru Dan Prestasi Belajar Siswa Pada Mata Pelajaran Pendidikan.” SIKIP Jurnal Pendidikan Agama Kristen 1, no. 2 (2020): 78-95.

Sidjabat, B Samuel. "Menjadi Guru Profesional Sebuah Perspektif Kristiani.” Jabar: IKAPIR (2000).

Simbolon, Naeklan. "Faktor-Faktor Yang Mempengaruhi Minat Belajar Peserta Didik." Elementary School Journal Pgsd Fip Unimed 1, no. 2 (2014).

Sumiati, Sumiati, Steaven Octavianus, and Reni Triposa. "Aplikasi Teori Kecerdasan Majemuk Pada Mata Pelajaran PAK Di Sekolah Inklusi." CHARISTHEO: Jurnal Teologi dan Pendidikan Agama Kristen 1, no. 1 (2021): 102-121.

Sumiati, Sumiati, and Reni Triposa. "Prinsip Guru Pendidikan Agama Kristen Memotivasi Belajar Peserta Didik Dalam Perspektif Alkitab." Harati: Jurnal Pendidikan Kristen 1, no. 1 (2021): 69-84.

Suparti, Hana, and Ezra Tari. "Etos Kerja Profesional Guru Pendidikan Agama Kristen." REGULA FIDEI: Jurnal Pendidikan Agama Kristen 4, no. 2 (2019): 137-146.

Syaparuddin, Syaparuddin, Meldianus Meldianus, and Elihami Elihami. "Strategi Pembelajaran Aktif Dalam Meningkatkan Motivasi Belajar Pkn Peserta Didik." Mahaguru: Jurnal Pendidikan Guru Sekolah Dasar 1, no. 1 (2020): 30-41.

Tafona'o, Talizaro. "Kepribadian Guru Kristen Dalam Perspektif 1 Timotius 4: 11-16." Evangelikal: Jurnal Teologi Injili dan Pembinaan Warga Jemaat 3 (2019): 62-81. 
Telaumbanua, Arozatulo. "Peranan Guru Pendidikan Agama Kristen Dalam Membentuk Karakter Siswa.” FIDEI: Jurnal Teologi Sistematika dan Praktika (2018).

Turangan, Danny Jonatan. "Kompetensi Pedagogik Guru Pendidikan Agama Kristen Berpengaruh Pada Motivasi Belajar Siswa Di Sd Gmim Ii Madidir Ure Kota Bitung." APOLONIUS: Jurnal Teologi dan Pendidikan Kristen 2, no. 1 (2021): 1-20.

Winarno, Surakhmad. "Pengantar Penelitian Ilmiah.” Bandung: Tarsito (1994).

Yulianingsih, Dwiati, Lumban Gaol, and Stefanus Marbun. "Keterampilan Guru PAK Untuk Meningkatkan Minat Belajar Murid Dalam Proses Pembelajaran Di Kelas." FIDEI: Jurnal Teologi Sistematika dan Praktika 2, no. 1 (2019): 100-119. 